
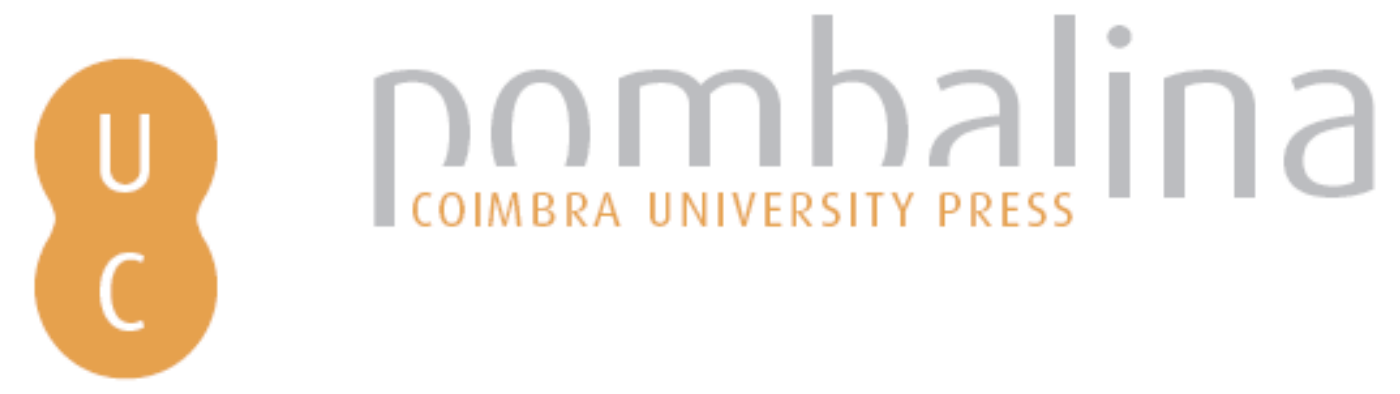

\title{
A propaganda oposicionista contra o Estado Novo durante os períodos eleitorais (19451973)
}

\author{
Autor(es): $\quad$ Lemos, Mário Matos e \\ Publicado por: Imprensa da Universidade de Coimbra \\ URL \\ persistente: URI:http://hdl.handle.net/10316.2/39011 \\ DOI: $\quad$ DOl:http://dx.doi.org/10.14195/978-989-26-1064-1_17 \\ Accessed : $\quad$ 26-Apr-2023 10:23:47
}

A navegação consulta e descarregamento dos títulos inseridos nas Bibliotecas Digitais UC Digitalis, UC Pombalina e UC Impactum, pressupõem a aceitação plena e sem reservas dos Termos e Condições de Uso destas Bibliotecas Digitais, disponíveis em https://digitalis.uc.pt/pt-pt/termos.

Conforme exposto nos referidos Termos e Condições de Uso, o descarregamento de títulos de acesso restrito requer uma licença válida de autorização devendo o utilizador aceder ao(s) documento(s) a partir de um endereço de IP da instituição detentora da supramencionada licença.

Ao utilizador é apenas permitido o descarregamento para uso pessoal, pelo que o emprego do(s) título(s) descarregado(s) para outro fim, designadamente comercial, carece de autorização do respetivo autor ou editor da obra.

Na medida em que todas as obras da UC Digitalis se encontram protegidas pelo Código do Direito de Autor e Direitos Conexos e demais legislação aplicável, toda a cópia, parcial ou total, deste documento, nos casos em que é legalmente admitida, deverá conter ou fazer-se acompanhar por este aviso.

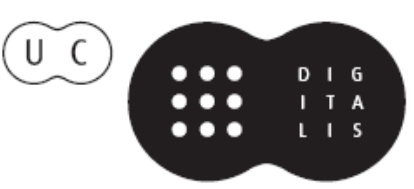


A L B ERTO PENA-RODR ÍGUEZ HELOISA PAULO

COOR D.

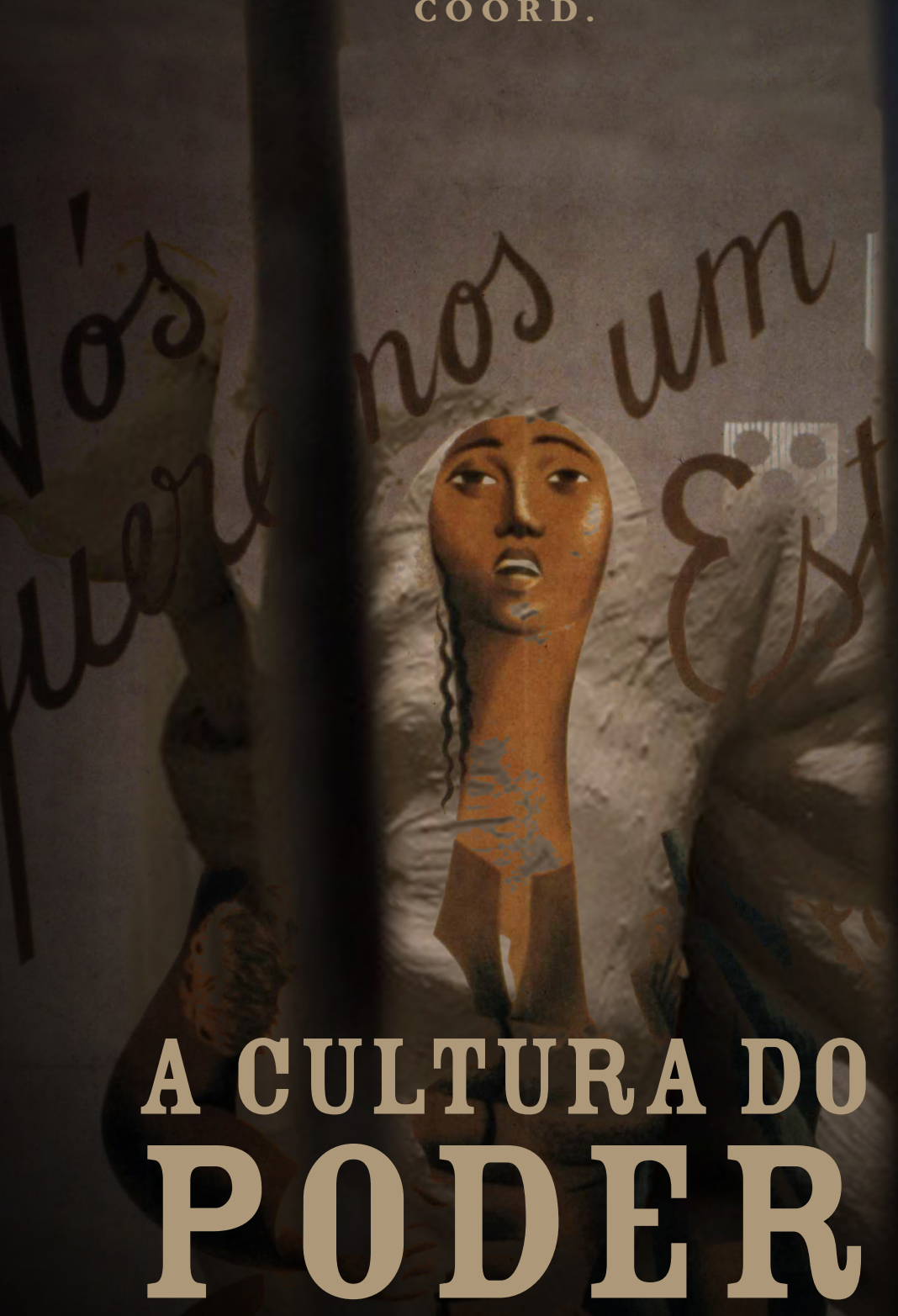

A PROPAGANDA INOS ESTADOS AUTORITÁRIOS 


\section{A PROPAGANDA OPOSICIONISTA \\ CONTRA O ESTADO NOVO \\ DURANTE OS PERÍODOS ELEITORAIS \\ ( 1945 - 1973 )}

Mário Matos e Lemos

Antes de entrar propriamente no tema, gostaria de recordar - e já direi porquê - que este termo propaganda pertence ao latim eclesiástico: um monge espanhol, Francisco de Jesus, publicou em Latim, no ano de 1613, um tratado sobre os métodos de evangelização no qual se encontrava um capítulo intitulado Sobre a criação de uma congregação da difusão da fé (propaganda fide, em Latim) e menos de uma década passada, em 1622, uma bula do Papa Gregório XV criou essa congregação.

Todavia, a aplicação prática do conceito, isto é, a difusão de uma ideia com vista a obter um benefício (que era a expansão da fé, na concepção da Igreja) foi, durante séculos, não só religioso mas também politico e ligado às esferas do poder, que eram as que tinham os meios avultados necessários para procurar ganhar o apoio dos sectores a que eram dirigidos. Para não recuar muito no tempo, passarei por cima de mestres da propaganda, como Júlio César, Carlos Magno ou Lutero e recordarei a actividade propagandística dos governos saídos da Revolução Francesa que, à falta de rádio, de cinema e de televisão fez proliferar as palavras de ordem revolucionárias, os 
escritos nas paredes (nada que os romanos não tivessem já feito, ainda durante a República), nos panfletos e até nas louças. O período napoleónico seguiu-lhe as pisadas erguendo arcos, colunas, compondo hinos, fazendo de David pintor da corte (como já o fora da monarquia) com o encargo de exaltar a figura de Napoleão e a sua política, juntando a tudo isto as proclamações e os boletins da Grande Armée.

Pouco mais de cem anos decorridos (e pondo de lado os exageros britânicos na propaganda durante a primeira guerra mundial) chegamos a Goebbels e ao seu Ministério da Consciencialização Pública e Propaganda, sumo exemplo da propaganda total e durável, com utilização de todos os meios possíveis na época: imprensa, rádio, cinema, cartazes, emissões de selos e de postais, indústria dos brinquedos, palavras de ordem, grandes encenações...

Todas estas referências à propaganda através dos séculos, extremamente incompletas e imprecisas, têm como único objectivo chamar a atenção para a importância que tem, para uma propaganda realmente efectiva, a utilização de todos os meios técnicos de qualquer época, utilização essa, só, repito, plenamente disponível para quem tem dinheiro e poder.

No caso do Estado Novo português, a sua máquina de propaganda dispunha, indiscutivelmente, de meios que, durante todo o tempo que durou, jamais estiveram ao alcance da oposição. A Rádio, a Imprensa, o Cinema e, já no meado do século, a Televisão, foram as grandes armas utilizadas pelo regime, inacessíveis a qualquer tipo de oposição que, ademais, ainda se via a braços com a Censura e com a Polícia Política.

Jornais, cartazes, livros, reuniões, tudo era cuidadosamente vigiado e só no final da guerra, em 1945, quando nova legislação permitiu a concorrência às urnas de candidatos que não apenas os da União Nacional, é que se tornou possível aos oposicionistas terem algum acesso à Imprensa, e quase só à Imprensa, para divulgarem 
os seus pontos de vista. Eram, no entanto, períodos curtos, 30 dias, o que quer dizer que, entre eleições legislativas e presidenciais, num arco de 336 meses, em apenas 11 foi permitida alguma liberdade de expressão, mesmo assim, sempre com a presença ameaçadora da Censura. As oposições aproveitarem-nos, porém, reconhecendo que essa liberdade condicionada permitia dar a conhecer posições que, como norma, só muito dificilmente, e recorrendo quase sempre a acções clandestinas, chegavam aos seus destinatários. Aqui, se o tema desta conversa fosse a propaganda das oposições contra o Estado Novo, ter-se-ia que falar extensamente da imprensa clandestina e da presença do Partido Comunista nessa imprensa, com os seus numerosíssimos títulos, seguindo a orientação leninista para a imprensa: cada actividade deveria ter o seu próprio órgão: é assim que em Portugal, para além do Avante, surgem títulos como O Têxtil, o Militante, o Corticeiro, etc.

Entrando já no tema - a propaganda durante as eleições - e sabendo-se que essas eleições decorreram entre 1945 e 1973, distingo três períodos:

1) O que vai de 1945 a 1957 , anos em que a principal preocupação era substituir o regime autoritário por uma democracia parlamentar; neste período, o ultramar (que acabaria por ser central na queda do regime) não só não era posto em causa, como era considerado parte integrante da Nação. Mário Lima Alves - o promotor da reunião de que nascerá o Movimento de Unidade Democrática - chegará a afirmar, nessa mesma reunião, que seria melhor continuar a designar por províncias ultramarinas os territórios a que a lei chamava agora colónias; e dois futuros candidatos à chefia do Estado - o general Norton de Matos e o almirante Quintão Meireles - eram firmes defensores da presença portuguesa no Ultramar. 
2) O que vai de 1958 a 1965 é marcado pela campanha presidencial do General Humberto Delgado cuja repercussão foi enorme, apesar das limitações, maiores do que o habitual, que o Governo impos. Valerá a pena recordar que na proclamação com que abriu a sua campanha, o general Delgado ainda falava na necessidade de "actualizar praticamente a integridade tradicional ultramarina".

3) O que vai de 1969 a 1973, que abrange as duas eleições marcelistas e que já está marcado por acontecimentos anteriores que não havia sido possível esconder: as greves estudantis de 1962 e 1969, os congressos de Aveiro (ao contrário do de 1957, que quase não teve eco), os movimentos dos católicos, as movimentações dos monárquicos ... Deu-se uma radical alteração na propaganda oposicionista, que dispunha de cada vez mais meios e que, por isso, ia chegando a também cada vez mais amplos extractos da população, atingindo em particular os militares. Ou seja: caminhava-se no sentido de alterar a opinião pública.

Embora toda a oposição procure fazer-se ouvir fora dos períodos eleitorais, é nessas ocasiões que se torna mais intensa e visível, ao mesmo tempo que reflecte o que se fora passando nos anos sem eleições. Um trabalho mais abrangente atingiria dimensões incompatíveis com o tempo, ou o espaço, disponível.

Vejamos, portanto, quais os principais meios a que os oposicionistas - ou a Oposição, para simplificar - recorriam, em período eleitoral para divulgar ideias e princípios. Eram eles, para além das sessões públicas e sem qualquer ordem hierárquica, os manifestos, os panfletos, as vinhetas, os cartazes (particularmente, nas eleições presidenciais, os que reproduziam a efígie dos candidatos), as entrevistas aos jornais, as conferências de imprensa, algumas com grande impacto, como foi o caso das que serviram para apresentar 
aos jornalistas as propostas do MUD, bem como as candidaturas dos generais Norton de Matos e Delgado, respectivamente em 1946 e em 1958, e o Programa para a Democratização da República, em 1961. Fora dos períodos eleitorais, predominavam os jantares de homenagem a figuras oposicionistas de reconhecido prestígio, a comemoração de datas como o 1 de Dezembro ${ }^{1} 5$ de Outubro ${ }^{2}$ ou o 31 de Janeiro ${ }^{3}$, com as suas romagens aos cemitérios, as representações ao Presidente da República, a que se procurava dar a maior divulgação possível. Claro que a evolução dos meios técnicos foi permitindo passar destas formas - a que haveria que juntar a imprensa clandestina, essencialmente do PCP - para outras, mesmo que com escasso impacto; e refiro-me às rádios, a Rádio Voz da Liberdade, que emitia de Argel, e à Rádio Moscovo, em português, que não só eram relativamente ouvidas como forneciam informações - verdadeiras ou falsas, não importa para o caso - a jornais e a outras estações emissoras estrangeiras provavelmente mais escutadas em Portugal do que aquelas. As emissões da Rádio Moscovo preocuparam o governo e, a certa altura, a Emissora Nacional passou a emitir um programa intitulado A verdade é só uma, Rádio Moscovo não fala verdade.

\section{A Imprensa e as tentativas da Oposição Republicana para ter um órgão próprio}

Desde que a oposição foi autorizada a apresentar candidatos às eleições (para a Assembleia Nacional, entre 1945 e 1973, e para a

${ }^{1}$ Data da restauração da soberania de Portugal em 1640, com a substituição da dinastia filipina pela de Bragança

2 Data da implantação da República, em 1910.

3 Data da primeira revolta republicana, ocorrida no Porto em 1891. 
Presidência da República, neste caso apenas por três vezes,1949, 1951 e 1958) que a Oposição apresentou uma reivindicação (fazia parte da lista de exigências apresentadas pelo Dr. Mário Lima Alves em 8 de Outubro de 1945) que se tornou constante até ao 25 de Abril: liberdade de imprensa e autorização para a fundação de novos jornais, independentemente do condicionamento corporativo. Naturalmente que havia entre os oposicionistas a consciência da necessidade de difundir as suas posições por meio da imprensa diária e algumas tentativas foram feitas nesse sentido. Durante os primeiros períodos eleitorais, alguns jornais mostraram-se claramente a favor da oposição, particularmente os três grandes diários do Porto - Primeiro de Janeiro, Comércio do Porto e Jornal de Notícias -, o Notícias de Coimbra e a Gazeta de Coimbra (o Diário de Coimbra encontrava-se suspenso desde Julho de 1945), a Democracia do Sul, em Évora, a República e, menos acentuadamente, o Diário de Lisboa, na capital, mas parecia necessário e conveniente dispor de um órgão próprio e parece mesmo ter havido, em Outubro de 1945, uma tentativa de oposicionistas republicanos para negociar com a administração do Diário de Notícias, de Lisboa, jornal conservador, a compra das instalações por cerca de 27 mil contos ${ }^{4}$.

A posição dos jornais era, com efeito, uma preocupação para o Governo, a tal ponto que, em Dezembro de 1945, os serviços de censura elaboraram um mapa estatístico 5 , por distritos, mostrando como mudara, entre 1 de Outubro e 20 de Dezembro de 1945 (mais de um mês depois da campanha eleitoral), a posição da imprensa relativamente à política estadonovista: se - de acordo com essa estatística -, de um total de 223 jornais examinados em Outubro, e de 233 examinados em Dezembro, as publicações defensoras do Estado Novo subiram, em Lisboa, de 30 para 33 , as publicações eventual-

\footnotetext{
${ }^{4}$ ANTT - Legião Portuguesa, AG. 7989. Nt 1490.

5 ANTT - AOS/CO/PC 8 D docs. 691-694.
} 
mente defensoras do Estado Novo baixaram de 40 para 34, as hostis passaram a ser 8 , em vez de 1 , e as eventualmente hostis que eram 3 , subiram para 5. No Porto, foram examinados respectivamente 66 e 67 jornais e enquanto as publicações defensoras do Estado Novo passaram de 5 para 10 , as eventualmente defensoras baixaram de 25 para 13 e as hostis ou eventualmente hostis, que não existiam em Outubro, passaram a ser 6 e 3 respectivamente. No total de 22 cidades alvo deste inquérito, enquanto o número de publicações defensoras ou eventualmente defensoras do Estado Novo baixaram de 253 para 223, as publicações hostis ou eventualmente hostis subiram de 9 para 50. Claro que este mapa está mal elaborado (não indica, por exemplo, se houve novos jornais fundados nesse período e qual a sua orientação) mas os números mostram que a propaganda oposicionista teve algum impacto.

A ideia de que era importante dispor de um órgão da oposição manteve-se viva e no princípio dos anos cinquenta houve tentativas para comprar o vespertino República: elementos ligados aos meios republicanos parece terem chegado a constituir um grupo financeiro, de que fariam parte o Dr. Nuno Simões, antigo ministro da República, e o industrial Tomé Feteira, com o objectivo de comprar esse vespertino, então dirigido por um jornalista de convicções republicanas, Carvalhão Duarte, a fim de acentuar a sua orientação oposicionista, dando-lhe mais meios económicos e mantendo mesmo o director, o que evitaria quaisquer formalidades legais que pudessem inviabilizar a operação. Parece ter-se considerado, também, mais ou menos na mesma altura, a formação de um trust de que fariam parte o Primeiro de Janeiro, a Associação Industrial de Lisboa e alguns accionistas do Diário Popular. Mais tarde, já nos anos sessenta, outros casos surgiram. Em 1966, uma informação da PIDE dava conta de que o Jornal de Notícias, do Porto, fora adquirido pela empresa proprietária do Primeiro de Janeiro, também do Porto, e que «um lote de 8.000 acções do Diário Popular, de Lisboa, teria 
passado para as mãos de indivíduos politicamente suspeitos, se a União Nacional se não apressasse a comprá-lo». Correram rumores de que houve mesmo uma nova tentativa de compra do Diário de Notícias que a PIDE considerava "um pouco inquietantes". Em Janeiro de 1966, Castro Fernandes, antigo ministro e presidente da Comissão Executiva da União Nacional, escrevera ao próprio Presidente do Conselho, Oliveira Salazar, a propósito da venda da posição de o Século no Diário de Lisboa a um grupo de pessoas, que não se sabia bem quais fossem e cujo interesse Castro Fernandes considerava "suspeito»6. A posição acabaria por ser tomada pelo Banco Nacional Ultramarino, de que o próprio era administrador. Ainda em 1966, houve o caso da tentativa de passar outro diário, $A$ Voz, para «um grupo esquerdista" que a PIDE não identifica. ${ }^{7} \mathrm{Em}$ Dezembro de 1971, a PIDE também anunciava que "padres e bispos progressistas tentaram já [por] três vezes apoderarem-se do jornal Novidades e só não o conseguiram pela oposição do Padre Moreira das Neves, chefe da redacção, sempre apoiado pelo Cardeal Cerejeira». Outra informação da PIDE, esta datada de 7 de Junho de 1971, afirma que numa reunião da Associação Internacional de Juristas realizada em Madrid e a que compareceram "vários elementos da oposição portuguesa» fora decidida a compra do vespertino República.

\section{Tentativa para transformar o MUD em Partido Político}

Foi em torno do MUD, e com base nas conclusões dessa reunião que todos os circunstantes subscreveram, que a oposição se reuniu, tentando, sem o dizer abertamente, transformar o movimento num partido político poderoso e reconhecido pelas autoridades constituídas.

\footnotetext{
${ }^{6}$ ANTT - AOS/CO/PC 57 - docs. 423-426.

7 Id., ibid., docs. 7-9.
} 
Os jornais, aproveitando o ligeiro abrandamento da censura deram ampla divulgação ao que se ia passando e começaram a publicar os nomes de quem ia aderindo às reivindicações apresentadas no Centro Almirante Reis. De entre essas reivindicações - praticamente todas se mantiveram até à queda do regime, em 1974: a revogação das leis regulamentares que condicionavam as garantias individuais contidas no art. $^{\circ} 8 .^{\circ}$ da Constituição Política de 1933 , a liberdade de expressão do pensamento sob qualquer forma, o alargamento do recenseamento eleitoral, a liberdade de reunião e de associação, a extinção do campo de concentração do Tarrafal (e, nessa linha, posteriormente, a libertação dos presos políticos) a formação de partidos políticos que pudessem estruturar o pensamento e actividades políticas da opinião pública.

No dia 10 de Outubro do mesmo ano de 1945, o MUD apresentou ao Governo e ao Presidente da República estas reclamações, as quais, naturalmente, não foram atendidas, o que não impediu que por todo o país se organizassem reuniões que atingiram rapidamente uma dimensão que parece ter surpreendido o Governo, a tal ponto que menos de uma semana depois já havia reacções oficiais que preocuparam seriamente os mais directos responsáveis pelo MUD.

Estamos já perante uma das principais formas de propaganda oposicionista em período eleitoral: reuniões (no Porto, por exemplo, a sessão realizada no dia 13 de Outubro, no Teatro Olímpia, foi transmitida para a rua por meio de altifalantes). Claro que não só não foram autorizados novos jornais como, procurando limitar a repercussão, o governo não autorizou os jornais a publicar quaisquer fotografias dessas sessões, o que não impedia que tivessem alguma repercussão: em carta datada de 14 de Outubro, Silvério de Magalhães, primo do Prof. Barbosa de Magalhães, uma das principais figuras do MUD, refere-lhe o entusiasmo com que decorrera a reunião: "A sala estava repleta e a rua Passos Manuel, desde a esquina 
da rua de Santa Catarina, até ao Largo de Santo André, estava à cunha. Ordem, Respeito e Civismo, foi a característica da multidão mas, quando se tratava de entoar A Portuguesa, o entusiasmo era profundo e os vivas eram delirantes. As próprias senhoras que assistiam, na sua maioria novas, algumas licenciadas, acompanhavam os homens com a mesma alegria e impetuosidade. Recordei-me com saudade dos tempos da propaganda." Da propaganda do Partido Republicano, entenda-se.

A difusão das ideias do MUD vingou. O governador civil de Leiria informava o ministro do Interior de que "em todos os concelhos deste distrito se têm organizado grupos do movimento de oposição "mud", com uma rede de ligações a qual, tendo a sua sede nos concelhos, se ramifica até às freguesias» e acrescentava: "a este movimento estão aderindo pessoas até agora fora da política e algumas que, fazendo até este momento parte das nossas fileiras, ou por não sentirem da nossa parte organização ou devido a razões de ordem pessoal ou, ainda, a um irrequietismo a que não são estranhas, começam também a ingressar na oposição, procurando um dinamismo que sentem faltar-nos ou satisfação duma ânsia de justiça que não têm conseguido. Mercê de tudo isto tem-se a organização do mud feito a um ritmo acelerado e completamente à vontade» ${ }^{8}$.

Este período que vai de 8 de Outubro até às eleições, em 18 de Novembro, é dos que vê reunir mais intensos meios de propaganda: em primeiro lugar, as reuniões públicas para apresentação das reivindicações apresentadas no Centro Escolar Republicano Almirante Reis: mais de 60 por todo o país, incluindo sessões em Bissau, em Luanda e em Lourenço Marques (hoje Maputo). Depois, a grande cobertura dada pelos jornais, com entrevistas, artigos e fotografias de numerosas individualidades oposicionistas. Houve ainda problemas com as candidaturas em Portalegre, onde foram apresentadas duas listas de

8 ANTT - Ministério do Interior, Gabinete do Ministro, Mç. 542, Nt. 419. 
oposição à da União Nacional, acabando por uma só ser aprovada mas com os candidatos a resolver apresentar-se na lista da União Nacional. Todavia, o que mais preocupou, nessa altura, o Governo, foi o aparecimento nos jornais de muitas centenas de assinaturas de médicos, escritores, engenheiros, advogados, arquitectos, gente dos mais variados quadrantes, apoiando as teses oposicionistas. A certa altura, os representantes do MUD já falavam em 50.000 assinaturas e isso provocou a abertura de um inquérito 9 à autenticidade dessas assinaturas e um endurecimento da censura.

O MUD e o Partido Comunista, que manteve sempre a sua independência relativamente aos outros agrupamentos oposicionistas, reagiram com comunicados, com o envio de moções e de representações ao Presidente da República, ora pedindo o adiamento das eleições, com o pedido de audiências ao Chefe do Estado - uma forma de tentar obrigar as autoridades a reconhecer o MUD como partido - com a distribuição de panfletos, esclarecendo as suas posições ou denunciando as atitudes, que considerava irregularidades, dos poderes oficiais. Deve também salientar-se a moção que os oposicionistas de Moçambique aprovaram e comunicaram ao Governador- Geral da então colónia, em 23 de Outubro de 1945, com o pedido de ser remetida ao Governo central. A importância desta moção advém do facto de emanar de oposicionistas que viviam no Ultramar e que vinham apoiar as reivindicações do MUD. Todavia, o documento mais importante foi, sem dúvida, a declaração ${ }^{10}$ lida pelo advogado Mário Lima Alves no Centro Escolar Republicano Almirante Reis, que durante muitos anos constituiu uma referência para os movimentos oposicionistas.

\footnotetext{
9 As conclusões desse inquérito, se as houve, nunca foram publicadas.

10 ANTT - Ministério do Interior, Gabinete do Ministro, Mç. 540, Nt 497.
} 


\section{Dupla Eleição em 1949}

Em 1949, deviam realizar-se duas eleições: uma para a Assembleia Nacional, em 13 de Novembro, a que concorreram apenas três círculos, e outra para a Presidência da República, em 13 de Fevereiro. Para a oposição, não eram as eleições legislativas as mais importantes: a entrada de deputados na Assembleia Nacional nunca seria em número suficiente para derrubar o Governo. Em contrapartida, se fosse possível à oposição eleger o Presidente da República a demissão do Governo era uma das competências do Chefe do Estado ${ }^{11}$. Recorde-se a célebre frase do General Humberto Delgado nas eleições de 1958: interrogado por um jornalista sobre o que, caso fosse eleito para a chefia do Estado, aconteceria ao Presidente do Conselho, a resposta foi: «Obviamente, demito-o». Todavia, estamos em 1949 - ano em que o calendário impõe duas eleições - legislativas e presidenciais - e o ambiente ainda não está tão radicalizado.

Nos intervalos entre eleições, a oposição mantinha-se activa e procurava dar a conhecer as suas iniciativas, ora através dos jornais, se a censura autorizasse, ora por meio de panfletos distribuídos mais ou menos clandestinamente, e digo mais ou menos porque em muitos casos esses panfletos cumpriam as exigências legais de indicação da tipografia onde eram impressos, pelo que eram legais, mas quando começavam a circular as autoridades apreendiam-nos.

Como se disse, por esta altura uma das formas de propagação das ideias oposicionistas era as representações ao Chefe do Estado, como aconteceu, por exemplo, em Janeiro de 1946: o Presidente da República, General Carmona, tinha aberto a sessão legislativa de 1945-1949 com um discurso em que apelava à colaboração entre

11 Uma circular de 1948 salientava a "relevância do argo em disputa" pois, de acordo com a Constituição vigente, compete ao Chefe do Estado "nomear e demitir o Presidente do Conselho e os Ministros» e "dar à Assembleia Nacional poderes constituintes». Cf. ANTT - NAUS - ACLC - MAI - GBT . 013, cx. 003, doc. 1101, 
todos os Portugueses, o que foi objecto de contestação da parte do MUD que renovou a queixa de falta de direitos e garantias, "entre os quais avultam as liberdades públicas fundamentais de todo o cidadão que, embora consignadas na Constituição Política, não passam de meras afirmações em conteúdo». Outros cavalos de batalha da Oposição eram a questão do recenseamento e a revisão da lei eleitoral, pontos consensuais entre os diversos sectores oposicionistas - a que só por comodidade, se chama Oposição, como se ela fosse una.

As próprias candidaturas presidenciais - a do General Norton de Matos (em 1949), a do Almirante Quintão Meyrelles (em 1951) e a do General Humberto Delgado (em 1958) - não foram, inicialmente, consensuais, embora acabassem por ser apoiadas por quase todos, comunistas incluídos.

Norton de Matos anunciou a sua decisão de concorrer à eleição contra o General Carmona numa reunião para que convocou jornalistas portugueses e estrangeiros e em que apresentou o seu "Manifesto à Nação» em que expunha o seu programa. A repercussão deste manifesto foi grande apesar de os jornais não terem sido autorizados a publicar mais do que uma pequena notícia na qual se dizia simplesmente: "O Sr. General Norton de Matos convidou ontem os representantes da Imprensa nacional e estrangeira, aos quais declarou as razões da sua candidatura, apresentada como de revolução contra o actual regime, e expôs o seu programa.» $\mathrm{Na}$ expressão do vespertino República, tratava-se de uma "pequena e falsa notícia imposta pelas autoridades", falsa, seguramente, por falar em "revolução contra o actual regime». Fosse como fosse, o manifesto, impresso aos milhares, teve uma enorme distribuição e o próprio General desde o início de 1948 que se desdobrava em visitas e contactos por todo o País. Todavia, o caminho não era fácil e Norton de Matos por duas vezes escreveu a Salazar queixando-se das dificuldades que a sua candidatura e os seus apoiantes encon- 
travam da parte das autoridades administrativas e policiais, e enviou várias representações ao Presidente da República, tanto antes como depois de a candidatura de Carmona ter sido oficialmente aceite, em 18 de Dezembro de 1948. A eleição foi marcada para 13 de Fevereiro de 1949 e as manifestações públicas de apoio ao candidato Norton de Matos, com a só foram autorizadas entre 3 de Janeiro e 11 de Fevereiro. A campanha foi marcada pelos comícios em diferentes pontos do país, pelas entrevistas aos jornais, pelos artigos que na imprensa publicavam os seus apoiantes mas sempre enfrentando a censura: no dia 9 de Fevereiro o General, face às "ameaças que envolvem o acto eleitoral próximo numa atmosfera irrespirável de coacção", escreve a Salazar exigindo a alteração das condições em que decorria a campanha e ameaçava desistir da candidatura. A resposta do Presidente do Conselho não o satisfez e na noite do dia seguinte anunciou a desistência, por não terem sido satisfeitas as suas exigências políticas mínimas. A decisão do General teve enorme repercussão - a Censura não podia impedir a sua divulgação - mas não agradou a todos os seus apoiantes, pois muitos entendiam que a candidatura devia ter ido até ao fim, enquanto outros, designadamente os comunistas, pretendiam a desistência pois no que estavam interessados era na agitação provocada pela campanha e não propriamente na eleição de um homem reconhecidamente anticomunista. $\mathrm{O}$ resultado foi o aparecimento de duas organizações oposicionistas: a oposição republicano-liberal reunida num Directório Democrato-Social, e os comunistas, que formaram o Movimento Nacional Democrático, que se apresentava como continuador do MUD.

Esta cisão teve a maior importância nas três eleições seguintes: as legislativas de 1949 e 1953 e as presidenciais de 1951, estas convocadas antecipadamente devido ao falecimento do General Carmona. 


\section{As Presidenciais de 1951}

Entretanto, o relativamente inesperado falecimento do General Carmona ${ }^{12}$, em Abril de 1951, obrigou à realização de uma nova eleição presidencial, pelo que os oposicionistas puderam voltar à liça ao fim de aproximadamente ano meio. Surgiram dois candidatos oposicionistas: o Prof. Ruy Luiz Gomes, apoiado pelo Movimento Nacional Democrático, e o Contra-Almirante Manuel Carlos Quintão Meyreles, que tinha o patrocínio do Directório Democrato-Social. O primeiro, apresentou-se com um manifesto, intitulado "Ao Povo", no qual afirmava que a sua candidatura se situava «no conjunto das reivindicações do MND, reivindicações que convergem para três objectivos fundamentais: República e Liberdade, Pão e Trabalho, Independência Nacional e Paz». O segundo era um dissidente do 28 de Maio e tinha o apoio do General Norton de Matos, cuja primeira escolha fora, no entanto, o Prof. Egas Moniz, que recusou, alegando motivos de saúde. Quintão Meyrelles era também o candidato de António Sérgio e dos dissidentes do Estado Novo, particularmente dos monárquicos, mas repudiara expressamente, em comunicado, "quaisquer entendimentos, ligações ou forma de aparentamento com o grupo que propõe a candidatura do Sr. Prof. Ruy Luiz Gomes, ou com quaisquer grupos ou partidos cuja acção se encontre directa ou indirectamente na dependência de uma potência estrangeira». Ruy Luiz Gomes desenvolveu intensa actividade de propaganda da sua candidatura, apresentando-se em comícios, assinando manifestos e protestando, junto do próprio Salazar, contra as dificuldades que as autoridades policiais lhe levantavam e, por fim, contra uma agressão de que fora alvo, tal como vários correligionários, à saída de uma

12 Quando a União Nacional discutiu o nome do candidato a propor para a Presidência da República, chegou a pensar-se noutro nome, dada a avançada idade de Carmona e o seu delicado estado de saúde. 
sessão de propaganda em Rio Tinto. Manifestos, comunicados, cartazes com a efígie do candidato apoiaram a campanha que encontrou grandes dificuldades para conseguir a cedência de salas onde pudesse realizar as suas sessões. O Supremo Tribunal de Justiça viria a considerar inelegível Ruy Luiz Gomes mas considerou elegíveis Quintão Meyrelles e, naturalmente, o candidato da União Nacional, que era o General Francisco Higino Craveiro Lopes. O agora único candidato oposicionista apresentou o seu manifesto em 4 de Julho enunciando quinze propósitos para a sua governação mas deixando bem claro que não tencionava «derrubar um regime, promover uma convulsão, agitar uma nova ideologia». Escreveu depois uma carta ao candidato da União Nacional, apelando à solidariedade militar para que fosse evitada a fraude eleitoral. A campanha prosseguiu e a Imprensa pôde dar-lhe bastante cobertura, como, aliás, também a dera a Ruy Luiz Gomes, o que provocou as iras da União Nacional que, em reunião da sua comissão executiva, propôs o endurecimento da censura, como forma de evitar futuramente a divulgação de manifestos e panfletos dos candidatos, solicitando-se que fossem tomadas providências legislativas para esse efeito.

\section{As Legislativas de 1953 e de 1957}

Sob o ponto de vista de propaganda das candidaturas, nada de relevante se passou nestas duas eleições Nas legislativas de 1953, o Movimento Nacional Democrático manterá a posição abstencionista que tomara em 1949, indo mesmo mais além: decidiu "considerar como não representando a oposição democrática quaisquer candidaturas, mesmo que formalmente não apareçam incluídas na lista da União Nacional». Esta atitude poderá ter contribuído para o fraco número de candidatos que se apresentaram apenas em três círculos (Castelo Branco, Portalegre e Vila Real).Quatro anos mais 
tarde, em 8 de Novembro, o número de círculos que concorreram foi de apenas 4 (na realidade 3 , pois além de Lisboa e do Porto, Aveiro apresentava-se com duas listas, uma das quais se proclamava nacionalista e não pretendia propriamente opor-se ao regime mas sim resolver problemas locais». Apesar do escasso número de candidatos e da posição do MND a actividade propagandística foi muito intensa, talvez até pelo facto de haver concorrentes de Lisboa e do Porto e por se ter dado uma ruptura entre republicanos e comunistas. Com efeito, o Movimento Nacional Democrático (MND) não só voltava a preconizar a abstenção, à semelhança do que fizera em 1949, como chega ao ponto de considerar que a apresentação de quaisquer candidaturas era um acto de colaboração com o regime. Os republicanos repudiaram esta interpretação e pela voz de um dos candidatos por Aveiro, Basílio Lopes Pereira, que afirmava escrever em nome individual mas «certo de que exprime nas suas linhas gerais a opinião dos seus ilustres companheiros de lista». Lopes Pereira, que sempre combatera a Ditadura Militar e o Estado Novo e chegara a cumprir uma pena de prisão, acusa o MND de simplesmente servir a causa do alargamento do imperialismo soviético e de ser "apenas mais uma nova alcunha dos chamados comunistas, melhor lhes chamaríamos soviéticos». Também Cunha Leal, antigo chefe de Governo, em declarações à República ${ }^{13}$, embora afirme compreender os abstencionistas explica por que motivos prefere a acção: "A Oposição não tem outras oportunidades para revelar a constância da sua fé, a não ser estes curtos períodos eleitorais, e ainda assim de forma restritiva [...]. Não se trata de vencer eleições: trata-se, isso sim, de afirmar princípios e de fazer acto de presença.»

Foi uma campanha intensa que decorreu nos moldes habituais: comícios com os discursos dos candidatos, manifestos com o programa dos vários círculos, entrevistas dadas aos jornais pelos candidatos

139 de Outubro de 1953. 
e por outras personalidades, comunicados dos diversos partidos chame-se-lhes assim por comodidade - existentes ou que surgem sem se saber de onde, como um Partido Cristão Democrático e um Movimentos das Mulheres Portuguesas, que se afirmam «em organização" mas que desaparecem tão depressa como apareceram. É o caso, também, de um Movimento Nacional Popular, desconhecido mas de que se afirma líder o monárquico Rolão Preto, e de uma Comissão Executiva Socialista do Distrito de Lisboa para não falar do ainda sobrevivente Partido Republicano Português. Os temas abordados ao longo da campanha são também os usuais: educação, economia, saúde, sindicalismo e problemas rurais. Pela primeira vez, os candidatos oposicionistas - dado que todas as listas de voto estão impressas em papéis iguais - vão a votos, com resultados modestos mas que, no contexto da época, é difícil dizer se são reais.

O ano das eleições de 1957 não foi diferente dos anteriores, no que à campanha se refere: as mesmas reivindicações, com relevo para os pedidos de garantias eleitorais, pedidos esses nunca atendidos, o que acabou por levar à desistência dos candidatos que se apresentavam por cinco círculos (Lisboa, Porto, Braga, Aveiro e Faro), De notar que este ano os comunistas pretendiam ir às urnas, abandonando a posição abstencionista dos anos anteriores, e foi o Directório Democrato-Social que preferiu abster-se de ir às urnas no dia 3 de Novembro, "perante a recusa tácita ou declarada do Governo em promover a realização de eleições livres» - citando os termos de uma exposição entregue ao Presidente da República. A Legião Portuguesa organizou uma estatística dos temas tratados durante a campanha: problemas económicos, 98; garantias eleitorais, 65; exercício de liberdades, 56; abstencionismo e intervencionismo, 53; problemas políticos, 4; Goa, 6; Assembleia Nacional, MUD e Ultramar, 3 cada. No entanto, entre 1953 e 1957 haviam ocorrido alguns acontecimentos importantes que marcariam futuras campanhas: destacam-se, em 1954, o agudizar dos problemas com a União 
Indiana que reivindicava a soberania sobre o então Estado Português da Índia e que levaram a graves confrontos no território. Não se terá percebido na altura mas esta "questão de Goa" viria a contribuir para a paulatina mudança de atitude da oposição relativamente às possessões ultramarinas portuguesas. O Governo era então criticado pela sua "má política" em relação ao caso de Goa mas essa crítica, como se lê numa representação dirigida em fins de Julho ao Presidente do Conselho - assinada por destacados oposicionistas -, era feita «à luz da sagrada herança do ultramar». Em 1955, o Partido Comunista toma posição no seu órgão oficial, o Avante, a favor da "luta libertadora dos povos de Goa, Damão e Diu» mas no ano seguinte, no seu V Congresso (III ilegal), o Partido Comunista vai mais longe e aprova um documento em que pela primeira vez se afirma o direito à independência dos povos das colónias portuguesas.

\section{A Candidatura do General Delgado em 1958}

O ano de 1958 - que seria o último em que as eleições presidenciais se realizaram por sufrágio universal - foi marcado pela candidatura do General Humberto Delgado, com uma mobilização de meios de propaganda e uma repercussão na opinião pública que nenhuma das anteriores campanhas presidenciais havia tido. Não foi tarefa fácil para a oposição, que desde 1957 vinha debatendo se devia ou não apresentar um candidato, primeiro chegar a um consenso, depois encontrar um nome. Os jornais iam procurando dar conta do que se passava mas a censura obstava ao pleno conhecimento dos comunicados. Todavia, iam surgindo nomes de candidatos oposicionistas possíveis: Craveiro Lopes, ainda presidente da República mas que se sabia não seria o candidato da União Nacional, Cunha Leal, Quintão Meyrelles, Jaime Cortesão, Mário de Azevedo Gomes, Humberto Delgado, entre outros. Além do Partido Comunista, havia outros movimentos 
oposicionistas que estavam activos no processo, como o Directório Democrato-Social, as Comissões Cívicas Eleitorais (dominadas pelos comunistas), ou o Directório do Partido Republicano. Sucediam-se os comunicados, as declarações e os jantares de homenagem. O nome que durante mais tempo esteve indigitado como candidato à Presidência foi o do Eng ${ }^{\circ}$. Cunha Leal, fortemente apoiado pelo Partido Comunista, apesar das hesitações do próprio, a braços com problemas de saúde. O Partido Comunista chegou a anunciá-lo oficialmente como seu candidato num panfleto em que se anunciava ao "Povo de Lisboa" que "a oposição tem um candidato democrático", Cunha Leal, o mesmo panfleto em que se dizia que o candidato independente, Humberto Delgado, «não dá garantias às forças democráticas para que lhe confiem um papel dirigente». Cunha Leal acabaria, efectivamente, por desistir, deixando já muito pouco tempo ao Partido Comunista para encontrar um substituto. A escolha acabaria por recair no Advogado Arlindo Vicente que apresentou o seu Manifesto, no qual seis pontos resumiam «as tarefas fundamentais que se impõem ao Governo", designadamente "a restauração de todas as liberdades democráticas" e "a modificação da actual política ultramarina, pela organização do seu trabalho e pela coordenação dos sectores económicos da metrópole e do das diversas parcelas do território ultramarino em bases igualitárias com vista a reforçar os laços comuns de amizade e cooperação». Por seu turno o General Humberto Delgado, que sobre Quintão Meyrelles tinha a vantagem de estar no activo, dirigiu uma proclamação "A Todos os Portugueses da Metrópole e do Ultramar», na qual garantia a sua intenção de não se "retirar nas vésperas da disputa eleitoral" e apresentava os dez pontos básicos em que se resumia o programa da sua candidatura: entre eles, promulgar nova lei eleitoral e organizar novo recenseamento, "a fim de serem realizadas a curto prazo, eleições gerais», bem como "actualizar praticamente a integridade tradicional ultramarina, cujos fundamentos são a unidade espiritual, política e 
económica de aquém e além-mar", e a igualdade de direitos de todos os seus constituintes".

Arlindo Vicente e Humberto Delgado começaram as suas campanhas separadamente mas se a do primeiro arrastou muita gente nos locais por onde passou, designadamente Lisboa, Porto, Coimbra e Faro, a do segundo tornou-se avassaladora, o que levou o Partido Comunista a decidir unir a candidatura de Vicente à de Delgado, por acordo celebrado a 30 de Maio, com vista a apresentar um único candidato na eleição de 8 de Junho. Os meios de propaganda foram os habituais mas conseguiram muito maior difusão, apesar de a censura estar particularmente atenta, principalmente evitando a publicação de fotografias que mostrassem multidões nos lugares por onde o General passava mas que eram reproduzidas pelos serviços de campanha do General e amplamente distribuídas. A própria repressão das autoridades policiais, com cargas de cavalaria, correrias e tiros, ajudou a publicitar a campanha. Mais grave: o Governo mandou tanques para o Terreiro do Paço, levando a imprensa estrangeira a publicar fotografias com uma simples legenda: «Budapeste? Não, Lisboa». Em Budapeste, recorde-se, dera-se, menos de um ano antes, a violenta repressão soviética a uma tentativa do povo húngaro para se libertar do domínio de Moscovo.

\section{As Legislativas de 1961 e de 1965}

A campanha do General Delgado despertou muitas jovens consciências para a política mas os acontecimentos que mediaram entre 1961 e 1965 foram determinantes para o reforço dessa consciência. Logo em Janeiro de 1961, o Capitão Henrique Galvão, antigo homem de confiança do regime mas que se tornou opositor, apareceu à frente de um grupo de portugueses e espanhóis que assaltou o navio mercante "Santa Maria»; em Março desse ano - depois de gra- 
ves incidentes em Luanda - começou a guerra em Angola; a poucos dias das eleições foi desviado um avião da TAP e lançados panfletos em Lisboa e noutras cidades, numa operação planeada também por Galvão; finalmente, já em Dezembro, as forças armadas indianas invadiram o Estado Português da Índia, Goa, para simplificar; e no último dia do ano deu-se a tentativa de assalto ao quartel de Beja. Importantes, também, foram os movimentos estudantis e o aparecimento de católicos a oporem-se, como tais, ao regime do Estado Novo, a mudança de posição dos monárquicos que de colaboração com a União Nacional passou a distanciar-se, e, acima de tudo, a apresentação do Programa para a Democratização de República aprovado em Janeiro e divulgado meses mais tarde numa conferência de imprensa com jornalistas portugueses e estrangeiros. Tudo acontecimentos que provocaram enorme comoção no país e que, naturalmente se refletiram, os três primeiros, nas eleições legislativas realizadas a 12 de Novembro desse ano, com candidatos oposicionistas a apresentarem-se em 10 círculos. A repercussão do Programa para a Democratização da República - que antes de ser publicado pelos jornais já circulava em cópias tiradas a stencil - foi enorme e a atitude do Governo - mandando interrogar, prender e instaurar processos a praticamente todos os signatários - contribuiu para lhe dar maior divulgação, favorecendo os interesses oposicionistas. O Programa foi, aliás, tanto em 1961 como em 1965 14, a base da campanha dos oposicionistas que continuavam a não ter acesso à Rádio nem à Televisão mas cujas ideias - para além das formas de divulgação habituais - sessões de propaganda pelo País, manifestos, panfletos, comunicados, representações, entrevistas aos jornais, etc. corriam mais facilmente em publicações legais como os boletins, jornais ou revistas das associações estudantis ou sindicais, muitas

14 Em 1965, o documento já estava desactualizado, principalmente face à evolução da guerra em três frentes - Guiné, Angola e Moçambique. 
vezes distribuídos à saída de liceus e universidades ou mesmo no meio da rua. Com o passar dos anos, estas publicações tornaram-se mais numerosas e mais diversificadas e atingiam um público muito mais vasto, chegando a ser lidas nos próprios teatros de guerra em África e contribuindo decisivamente para uma predisposição dos espíritos que permitiria a aceitação do movimento que em 25 de Abril de 1974 derrubaria o Estado Novo.

\section{As últimas eleições do Estado Novo}

Em Setembro de 1968, Salazar, gravemente doente, foi substituído por Marcello Caetano no cargo de Presidente do Conselho. Estava-se a pouco mais de um ano das eleições legislativas e os sinais de abertura dados por Marcello Caetano - como o abrandamento das intervenções da Censura, a autorização para o regresso do Dr. Mário Soares de S. Tomé e do Bispo do Porto, D. António Ferreira Gomes, do seu exílio, a autorização para a realização, em Aveiro, em Maio de 1969 e em Abril de 1973 dos II e III congressos da oposição democrática - foram de molde a convencer a oposição de que valeria a pena apresentarem-se às urnas, apesar de incidentes como a Velada pela Paz na igreja de S. Domingos, em Lisboa, as manifestações no funeral de António Sérgio e nas comemorações do 31 de Janeiro no Porto ou a revolta estudantil nas três grandes cidades universitárias: Lisboa, Coimbra e Porto. Assim, num total de 22 em 27 círculos possíveis, 182 candidatos entraram em liça para disputarem os 130 lugares de deputados na Assembleia Nacional, mais dez do que em anos imediatamente anteriores. A campanha foi, naturalmente, mais viva do que nunca, até por que a oposição não conseguiu unir-se: ainda se formou uma plataforma de Acção Comum do Movimento Eleitoral Democrático, que ficaria conhecida por Plataforma de S. Pedro de Moel, do nome da localidade onde se efectuaram as reuniões, mas 
a frágil unidade acabou por romper-se e a oposição acabou por se apresentar às urnas dividida entre Comissão Democrática Eleitoral e Comissão Eleitoral de Unidade Democrática, embora esta se tivesse apresentado apenas em quatro círculos: Lisboa, Porto, Braga e Moçambique. Houve também, em Lisboa, uma lista dos monárquicos, reunidos na Comissão Eleitoral Monárquica. Embora continuando as habituais restrições, mesmo sem acesso à Rádio e à Televisão, nunca as candidaturas oposicionistas haviam tido tanta divulgação como nestas eleições de 1969. É que, para além dos habituais comunicados, manifestos, panfletos e cartazes, grande parte da imprensa dedicava suplementos especiais às eleições ou dava-lhes grande atenção no corpo dos jornais e havia ainda as revistas, como a Seara Nova ou O Tempo e o Modo, a actividade da SEDES (Associação para o Desenvolvimento Económico e Social, fundada em 1970) e a imprensa clandestina de grupos radicais que haviam começado a aparecer, activíssimos, em meados dos anos 60. Sem esquecer também a imprensa da emigração, principalmente no Brasil, já antiga, e em França, mais recente, ou a actividade da Rádio Portugal Livre, emissora do Partido Comunista, a transmitir do estrangeiro desde 1962 ou a Rádio Voz da Liberdade, que emitia de Argel, em nome da Frente Patriótica de Libertação Nacional. Valiam o que valiam estes nomes e a sua acção mas a verdade é que ambas as estações iam sendo ouvidas em Portugal e transmitindo as posições oposicionistas.

A maneira como correram as eleições e os seus resultados constituíram uma profunda desilusão e o resultado foi uma enorme radicalização nos meios de acção. Não pode considerar-se propaganda todas as acções violentas que a partir de 1969 tiveram lugar mas que, sem dúvida, mostraram o amplo descontentamento em relação à política do Governo, principalmente em relação à política ultramarina. De salientar as posições tomadas pela denominada ala liberal, chefiada pelo Advogado Francisco Sá Carneiro, que muito contribuíram para desacreditar a política de Marcello Caetano, principalmente 
junto das classes médias urbanas. O semanário Expresso, fundado em 1973, foi um franco divulgador dessas posições. Nesse ano de 1973, ainda se realizaram eleições legislativas, a 28 de Outubro, as últimas do Estado Novo, mas foram praticamente ignoradas por toda a oposição, que, embora apresentando-se em 11 círculos, apenas pretendeu mostrar o seu descontentamento, para isso usando as tradicionais armas - panfletos, manifestos, comícios, etc. - só que com uma ressonância muito maior do que aquela que alguma vez havia tido, mesmo considerando 1969.

Em 28 de Outubro, já começavam a ser conhecidas as posições de um Movimento dos Oficiais, embrião de que sairia o movimento que, escassos meses passados, derrubaria o Estado Novo, em 25 de Abril de 1974.

\section{Bibliografia e fontes utilizadas}

Eleições no Regime Fascista - Lisboa, Comissão do Livro Negro sobre o Regime Fascista, 1979; Eleições Presidenciais: Subsídios para a História das Candidaturas de Norton de Matos (1949), Quintão Meireles (1951) e Humberto Delgado (1958) - Lisboa, Edições Delfos, s/d.; BRITO, J. M. Brandão de e ROSAS, Fernando. Dicionário de História do Estado Novo, 2 vols. Lisboa, Círculo de Leitores, 1996; COSTA, Marcus Noronha da e RUAS, Henrique Barrilaro (orgs.) Dossier da Comissão Eleitoral Monárquica de 1969, Braga, 1973; CRUZ, Manuel Braga da. "A Oposição Eleitoral ao Salazarismo", in: Revista de História das Ideias, Coimbra, 1983; LEMOS, Mário Matos e, e TORGAL, Luís Reis - Oposição e eleições no Estado Novo, Lisboa, Assembleia da República, 2012; LEMOS, Mário Matos e, e TORGAL, Luís Reis - Candidatos da Oposição à Assembleia Nacional do Estado Novo, Lisboa, Assembleia da República, 2009; MATOS, Norton de - Os Dois Primeiros Meses da Minha Candidatura à Presidência da República - 
Lisboa, Ed. do Autor, 1949; MATOS, Norton de - Mais Quatro Meses da Minha Candidatura à Presidência da República - Porto, Ed. do Autor, 1949; MEDINA, João - História de Portugal, vols. 12 e 13, Lisboa, Ediclube, 1993; MOURA, Virgínia (selec., pref. e ed.) - Eleições de 1969, Documentos eleitorais da Comissão Democrática do Porto, Porto, 1971; PAULO, Heloísa - Memória das Oposições (1927-1969) Coimbra, Minerva, 2010; PEREIRA, José Pacheco - As Armas de Papel, Lisboa, Temas e Debates, 2013; REBELLO, José Pequito - As Eleições de Portalegre (Documentos) - Lisboa, ed. do Autor, 1950; SOARES, Mário. Portugal Amordaçado: Depoimento sobre os Anos do Fascismo, Lisboa, Arcádia, 1974. TAVARES, Marília - Os Congressos Republicanos de Aveiro: Subsídios para a História da Oposição ao Estado Novo, tese de mestrado, Coimbra, Faculdade de Letras, 1994; TENGARRINHA, José. Os Caminhos da Unidade Democrática contra o Estado Novo. Coimbra, Revista de História das Ideias, vol. 16, 1994. 